\title{
Scientific note COMBINATION OF ISOLATES OF Pochonia chlamydosporia FOR THE CONTROL OF Meloidogyne javanica IN TOMATO
}

Déborah Magalhães Xavier ${ }^{1 *}$, Rosangela Dallemole-Giaretta ${ }^{2}$, Leandro Grassi de Freitas ${ }^{1}$, Everaldo Antonio Lopes ${ }^{3}$, Cristiane Gonçalves Gardiano ${ }^{4}$, and Silamar Ferraz ${ }^{1}$

${ }^{1}$ Universidade Federal de Viçosa, Departamento de Fitopatologia, 36571-000, Viçosa (MG), Brasil.

${ }^{2}$ Universidade Tecnológica Federal do Paraná, Câmpus Pato Branco, 85503-390, Pato Branco (PR), Brasil.

${ }^{3}$ Universidade Federal de Viçosa, Campus Rio Paranaíba, Instituto de Ciências Agrárias, 38810-000, Rio Paranaíba (MG), Brasil.

${ }^{4}$ Universidade Estadual de Londrina, Departamento de Agronomia, 86051-990, Londrina (PR), Brasil.

* Corresponding author E-mail: deborah_agro@hotmail.com

\section{ABSTRACT}

Three different isolates of Pochonia chlamydosporia (Pc-3, Pc-10 and Pc-28) were evaluated in a greenhouse experiment when applied individually and in combinations. A control treatment with no application of isolates of $P$. chlamydosporia var. chlamydosporia was included, while neither isolates nor nematodes were used in another untreated treatment. One-liter pots were filled with sterilized soil, and each pot was infested with $3 \mathrm{~g}$ of rice substrate colonized with the respective isolate plus 3,000 eggs of Meloidogyne javanica. One 'Santa Clara' tomato seedling was transplanted to each pot after fifteen days. None of the isolates (applied individually or in combinations) was able to reduce the number of galls when compared to the control treatment. However, the number of eggs of M. javanica decreased for isolates Pc-10 and mixtures Pc-10 + Pc-3, and Pc-10 + Pc-28 + Pc-3. The association of isolates of $P$. chlamydosporia var. chlamydosporia did not increase the control of $M$. javanica when compared to the application of Pc-10 individually.

Key words: biological control, nematodes, nematophagous fungi, root-knot nematode.

\section{RESUMEN}

El experimento se realizó en invernadero, donde se evaluaron tres aislamientos de Pochonia chlamydosporia (Pc-3, Pc-10 y Pc-28), que se aplicaron individualmente y en combinaciones. En el tratamiento testigo no se aplicó $P$. chlamydosporia var. chlamydosporia al suelo, y también se incluyó un tratamiento testigo sin nematodos. Vasos de un litro de capacidad con suelo esterilizado fueron infestados con $3 \mathrm{~g}$ de sustrato de arroz colonizados con el respectivo aislamiento del hongo más 3.000 huevos de M. javanica. Quince días más tarde, se trasplantó en cada vaso una plántula de tomate 'Santa Clara'. Ninguno de los aislamientos del hongo, en forma individual o en mezcla, fueron capaces de reducir el número de agallas en comparación con el tratamiento testigo. Sin embargo, el número de huevos de M. javanica se redujo para el aislamiento Pc-10 y las combinaciones de Pc-10 + Pc-3 y Pc-10 + Pc-28 + Pc-3. La asociación de los aislamientos de P. chlamydosporia var. chlamydosporia no aumentó el control de $M$. javanica en comparación con la aplicación de Pc-10 individualmente.

Palabras claves: control biológico, hongos nematófagos, nematodos. 


\section{INTRODUCTION}

Many studies have identified alternative control methods for plant parasitic nematodes. Biological control of plant parasitic nematodes is an important alternative due to the negative impact caused by the use of nematicides on the environment and on human health (Ferraz et al., 2010).

One of the most studied biological control agents is the fungus Pochonia chlamydosporia Zare \& Gams (sin. Verticillium chlamydosporium Goddard), which is a facultative parasite of eggs and females of both cyst and root-knot nematodes (Kerry and Bourne, 2002). This antagonist showed potential use as a biocontrol agent, both in greenhouse and field trials (Hernández and Hidalgo-Díaz, 2008). Isolates of $P$. chlamydosporia var. chlamydosporia, Pc-3, Pc-10, and Pc-28, selected in Brazil, when individually applied to the soil, were able to decrease the number of $M$. javanica eggs up to $80 \%$ (Lopes et al., 2007; Dallemole-Giaretta et al., 2008; Dallemole-Giaretta et al., 2012). This fungus can also be used in combination with other management techniques for plant parasitic nematodes, or applied with another antagonist to maximize the control of nematodes (Siddiqui and Ehteshamul, 2000; Cannayane and Rajendran, 2001). However, there are no reports on applications of two or more isolates of $P$. chlamydosporia to potentiate nematode control.

This fungus has desirable characteristics for a biocontrol agent, such as rhizosphere competition and colonization of roots of a wide range of plants. However, the colonization of the root system of plants differs according to the isolate of P. chlamydosporia (Bourne et al., 1994). Otherwise, it is known that roots infected by nematodes are more heavily colonized by the fungus than the roots of healthy plants (Bourne et al., 1994; Bourne et al., 1996).

The objective of this study was to evaluate the mixing of isolates of $P$. chlamydosporia var. chlamydosporia for the control of Meloidogyne javanica (Treub) Chitwood in tomato plants.

\section{MATERIALS AND METHODS}

Three isolates of $P$. chlamydosporia var. chlamydosporia (Pc-3, Pc-10, and Pc-28) were used in this study. These fungal isolates had already presented potential in controlling $M$. javanica in previous studies, and they belong to the mycology collection of the Laboratory of Biological Control of Plant Parasitic Nematodes (BIONEMA) of the Federal University of Viçosa (UFV - Universidade Federal de Viçosa), Brazil.

The isolates of $P$. chlamydosporia were cultivated on sterilized rice grains at $26^{\circ} \mathrm{C}$ for 21 days in the dark. After 21 days, the number of chlamydospores per gram of substrate was determined according to methodology described by Kerry and Bourne (2002). The chlamydospores production of isolates of $P$. chlamydosporia Pc-3, Pc-10, and Pc-28 were $1.75 \times 10^{5}, 3.12 \times 10^{6}$ and $1.32 \times 10^{6}$ per gram of substrate, respectively.

The experiment was conducted in the greenhouse of the UFV Department of Phytopathology $\left(20.7603^{\circ} \mathrm{S}, 42.8678^{\circ} \mathrm{W}\right)$. The treatments evaluated were the fungal isolates Pc-3, Pc-10, and Pc28 of $P$. chlamydosporia applied individually and combinations of isolates Pc-10 + Pc-28 + Pc-3; Pc-10 + Pc-28; Pc-28 + Pc-3, and Pc-10 + Pc-3. The fungus was not applied to the control treatments. The control without nematodes was used to confirm that there were neither nematodes nor fungus in the soil. The containers were arranged in a complete randomized block design with eight replications per treatment.

Pots of $1,000 \mathrm{~mL}$ of capacity were filled with a methyl bromide-fumigated mixture of soil and sand (1:1). Soil of each pot was placed into a plastic bag of $5,000 \mathrm{~mL}$ of capacity with $3 \mathrm{~g}$ of substrate colonized with the respective fungal isolate, homogenized manually and replaced in the pot. Then, the soil was infested with 3,000 eggs of $M$. javanica per pot. The nematode inoculum was put in four holes of approximately $5 \mathrm{~cm}$ of depth, with spacing of $5 \mathrm{~cm}$ in the center of the pot.

A single 21-day-old seedling of 'Santa Clara' tomato was transplanted into each pot 15 days after inoculation with both organisms. The pots were maintained at $60 \%$ field capacity for moisture and fertilized once a week. The average temperature in the greenhouse was $25^{\circ} \mathrm{C}$ and ranged from $18^{\circ} \mathrm{C}$ to $32^{\circ} \mathrm{C}$.

Evaluations of plant height, weight of fresh aboveground parts and root systems, and numbers of galls and eggs were evaluated 45 days after transplanting. Data were analyzed by analysis of variance (ANOVA) and means separated using Duncan's multiple range procedures, with $5 \%$ of probability.

\section{RESULTS AND DISCUSSION}

All of the treatments had significantly lower aboveground weights compared to the control treatment without fungus and nematode. It was found that the weight of aboveground parts of tomato plants cultivated in pots without nematodes was lower than those infested with $M$. javanica (Table 1). The application of fungal isolates Pc-3, Pc-10, and Pc-28 of P. chlamydosporia var. chlam$y$ dosporia to the soil, individually or combined did not reduce the number of galls of $M$. javanica when compared to the nematode alone treatment 
(Table 1). There was a significant difference in the number of $M$. javanica eggs per root when the fungal isolate Pc-10 was incorporated individually into the soil compared to the nematode alone (307.7 and 597.2 eggs per root, respectively).

Previous experiments (Lopes et al., 2007; Dallemole-Giaretta et al., 2012) with the same fungal isolates used in this experiment demonstrated that they are able to control the root-knot nematode. However, the results obtained in this study show that isolates Pc-3 and Pc-28 did not significantly reduce the number of eggs compared to the control untreated with the fungus.

Although many studies have been conducted with $P$. chlamydosporia, complex interactions between biotic and abiotic factors may influence the antagonistic potential of the fungus. Therefore, there is a need to identify the factors that affect virulence and growth of saprophyte isolates of $P$. chlamydosporia (Esteves et al., 2009).

One of the factors that may have affected the low effect of $P$. chlamydosporia isolates may be the quantity of inoculum used in this study. The quantity of inoculum applied to the soil was $5.25 \times 10^{2}$, $9.36 \times 10^{3}$, and $3.96 \times 10^{3}$ chlamydospores per gram of soil, of $P$. chlamydosporia var. chlamydosporia, isolates Pc-3, Pc-10, and Pc-28, respectively. In case of isolate Pc-3, the quantity of inoculum used was probably low. In general, the fungus is effective at $5 \times 10^{3}$ chlamydospores per gram of soil (Kerry, 2001; Dallemole-Giaretta et al., 2012). However, the possible reduction of chlamydospore availability may have affected the establishment of isolates Pc-3 and Pc-28 in the soil. Lopes at al. (2007) demonstrated the potential of isolate Pc-28 as a biological control agent against $M$. javanica, applying 300 chlamydospores of this isolate per gram of soil. However, they also reported that isolate Pc10 allowed the establishment and reproduction of the fungus on root systems when applied at a rate of $9.36 \times 10^{3}$ chlamydospores per gram of soil. The number of $M$. javanica eggs decreased by $48.47 \%$ (Table 1) when compared to the control treatment, confirming the potential of this isolate as a biocontrol agent of M. javanica (Dallemole-Giaretta et al., 2008).

The combined application of $P$. chlamydosporia var. chlamydosporia isolates was expected to decrease M. javanica populations. Isolates used in this study were selected because of the biocontrol action demonstrated in previous studies. Therefore, the mixture of antagonists must be compatible in order to control phytopathogens (Akrami et al., 2009; Lucon et al., 2009). An example of incompatibility of biological control agents was reported by Lucon et al. (2009). In this case, it was found that when applying five isolates of Trichoderma spp. to control Rhizoctonia solani only two combinations of isolates of the antagonist resulted in the control of $R$. solani.

In the present study, combinations of $P$. chlamydosporia isolates did not result in the control of $M$. javanica when compared to the application of the isolate Pc-10 individually. Further studies are required in the field to verify whether adverse conditions affect the synergism between isolates, or whether isolates of $P$. chlamydosporia tested will be incompatible.

Table 1. Effect of different combinations of Pochonia chlamydosporia isolates (Pc-3, Pc-10, Pc-28) on the growth of tomato plants and on the number of galls and eggs of Meloidogyne javanicaz

\begin{tabular}{lccccc}
\hline Treatments & $\begin{array}{c}\text { Height } \\
\text { Aboveground } \\
\text { weight }^{*}\end{array}$ & $\begin{array}{c}\text { Root } \\
\text { weight }\end{array}$ & $\begin{array}{c}\text { Galls per } \\
\text { root }\end{array}$ & $\begin{array}{c}\text { Eggs per } \\
\text { root }^{*}\end{array}$ \\
\hline Tomato & $\mathrm{cm}$ & $-------\mathrm{g}$ & --------- & $---------\mathrm{N}^{\circ}----------$ \\
without M. javanica. & $70^{\mathrm{ns}}$ & $37 \mathrm{a}$ & $6,83^{\mathrm{ns}}$ & - & - \\
Tomato (with M. javanica.) & 64 & $31 \mathrm{~b}$ & 8,45 & $916^{\mathrm{ns}}$ & $597.25 \mathrm{ab}$ \\
Pc-10 & 66 & $30 \mathrm{~b}$ & 6,95 & 803 & $307.74 \mathrm{c}$ \\
Pc-28 & 65 & $32 \mathrm{~b}$ & 7,64 & 911 & $476.09 \mathrm{abc}$ \\
Pc-3 & 66 & $31 \mathrm{~b}$ & 7,71 & 900 & $728.50 \mathrm{a}$ \\
Pc-10 + Pc-28 + Pc-3 & 62 & $32 \mathrm{~b}$ & 6,98 & 714 & $410.18 \mathrm{bc}$ \\
Pc-10 + Pc-28 & 66 & $31 \mathrm{~b}$ & 6.64 & 824 & $488.50 \mathrm{abc}$ \\
Pc-28 + Pc-3 & 60 & $32 \mathrm{~b}$ & 7,71 & 745 & $525.82 \mathrm{abc}$ \\
Pc-10 + Pc-3 & 63 & $31 \mathrm{~b}$ & 7,38 & 926 & $458.51 \mathrm{bc}$ \\
\hline
\end{tabular}

${ }^{\mathrm{z}}$ Mean of eight replications.

* Means followed by the same letter in a column do not differ of each other by Duncan's multiple range tests, at $5 \%$ of probability.

${ }^{\text {ns }}$ Not significant by the F test at $5 \%$ of probability. 


\section{CONCLUSION}

This experiment confirms the ability of $P$. chlamydosporia var. chlamydosporia isolates to reduce the number of $M$. javanica eggs. A range of variability was observed among the different isolates and their combinations. However, the combination of isolates was not able to increase nematode control. Studies about compatibility of isolates should help addressing the complex interaction among isolates, and host and pathogens.

\section{ACKNOWLEDGEMENTS}

The authors would like to thank the CNPq (Conselho Nacional de Desenvolvimento Científico e Tecnológico), FAPEMIG (Fundação de Amparo à Pesquisa de Minas Gerais) and CAPES (Coordenação de Aperfeiçoamento de Pessoal de Nível Superior) for their financial support.

\section{LITERATURE CITED}

Akrami, M., A.S. Ibrahimov, D.M. Zafari, and E. Valizadeh. 2009. Control of Fusarium rot of bean by combination of Trichoderma harzianum and Trichoderma asperellum in greenhouse condition. Agricultural Journal 4:121123.

Bourne, J.M., B.R. Kerry, and F.A.A.M. De Leij. 1994. Methods for the study of Verticillium chlamydosporium in the rhizosphere. Journal of Nematology 26:587-591.

Bourne, J.M., B.R. Kerry, and F.A.A.M. De Leij. 1996. The importance of the host plant on the interaction between root-knot nematodes (Meloidogyne spp.) and the nematophagous fungus, Verticillium chlamydosporium Goddard. Biocontrol Science and Technology 6:539-548.

Cannayane, I., and G. Rajendran. 2001. Application of biocontrol agents and oil cakes for the management of Meloidogyne incognita in brinjal (Solanum melongena L.). Current Nematology 12:51-55.

Dallemole-Giaretta, R., L.G. de Freitas, E.A. Lopes, O.L. Pereira, R.J.F. Zooca, and S. Ferraz. 2012. Screening of Pochonia chlamydosporia Brazilian isolates as biological control agents of Meloidogyne javanica. Crop Protection 42:102-107.
Dallemole-Giaretta, R., L.G. de Freitas, S. Ferraz, W.S. Neves, E.A. Lopes, e M.M. Coutinho. 2008. Efeito da concentração de clamidósporos de Pochonia chlamydosporia var. chlamydosporia no controle de Meloidogyne javanica. Nematologia Brasileira 32:329-334.

Esteves, I., B. Peteira, S.D. Atkins, N. Magan, and B.R. Kerry. 2009. Production of extracellular enzymes by different isolates of $\mathrm{PO}_{\mathrm{O}}$ chonia chlamydosporia. Mycological Resarch 113:867-876.

Ferraz, S. L.G. de Freitas, E.A. Lopes, e C.R. Dias-Arieira. 2010. Manejo sustentável de fitonematoides. 304 p. Editora UFV, Viçosa, Brasil.

Hernández, M.A. y L. Hidalgo-Díaz. 2008. Klamic®: Bionematicida producido a partir del hongo Pochonia chlamydosporia var. catenulata. Revista de Protección Vegetal 23:131-134.

Kerry, B.R. 2001. Exploitation of the nematophagous fungal Verticillium chlamydosporium Goddard for the biological control of rootknot nematodes (Meloidogyne spp.). p. 155167. In Butt, T.M., C. Jackson, and N. Magan (eds.) Fungi as biocontrol agents: progress, problems and potential. CAB International, Wallingford, UK.

Kerry, B.R., and J.M. Bourne. 2002. A manual for research on Verticillium chlamydosporium, a potential biological control agent for rootknot nematodes. 84 p. International Organization for Biological Control of Noxious Animals and Plants, West Palaearctic Regional Section, Gent, Belgium.

Lopes, E.A., S. Ferraz, P.A. Ferreira, L.G. Freitas, O.D. Dhingra, C.G. Gardiano, e S.L. Carvalho. 2007. Potencial de isolados de fungos nematófagos no controle de Meloidogyne javanica. Nematologia Brasileira 31:78-84.

Lucon, C.M.M., C.M. Koike, A.I. Ishikawa, F.R.A. Patrício, e R. Harakava. 2009. Bioprospecção de isolados de Trichoderma spp. para o controle de Rhizoctonia solani na produção de mudas de pepino. Pesquisa Agropecuária Brasileira 44:225-232.

Siddiqui, I.A., and S. Ehteshamul-Haque. 2000. Effect of Verticillium chlamydosporium and Pseudomonas aeruginosa in the control of Meloidogyne javanica on tomato. Nematologia Mediterranea 28:193-196. 